http://ojs.umrah.ac.id/index.php/kiprah

\title{
Proses Berpikir Kritis Siswa dalam Menyelesaikan Masalah PISA ditinjau dari Kemampuan Berpikir Komputasi
}

\author{
Ayu Chinintya Lestari, Anas Ma'ruf Annizar* \\ Tadris Matematika, IAIN Jember, Jember, Indonesia \\ Pengiriman: 23/02/2020; Diterima: 21/06/2020; Publikasi: 30/06/2020 \\ DOI: https://doi.org/10.31629/kiprah.v8i1.2063
}

\begin{abstract}
Abstrak
Kemampuan bernalar maupun berpikir kritis siswa Indonesia pada jenjang SMP masih belum optimal. Hal ini dapat dilihat dari OECD 2019 yang menyebutkan bahwa hasil PISA pada tahun 2018, posisi Indonesia berada pada peringkat ke-7 dari bawah. Salah satu cara meningkatkan kemampuan berpikir kritis adalah membiasakan siswa menerapkan berpikir komputasi, yakni proses berpikir dalam memecahkan masalah yang kompleks dengan berbagai cara yang sederhana. Oleh sebab itu, penelitian ini bertujuan untuk mendeskripsikan proses berpikir kritis ditinjau dari kemampuan berpikir komputasi siswa. Adapun metode yang digunakan dalam penelitian ini adalah deskriptif dengan pendekatan kualitatif. Teknik pengumpulan data dilakukan dengan tes dan wawancara. Penentuan subjek menggunakan teknik purposive sampling dengan mengambil 3 subjek usia 15 tahun jenjang SMP yang memilki kemampuan berpikir komputasi tinggi, sedang, dan rendah. Hasil penelitian menunjukkan bahwa dalam proses mengerjakan instrumen tes berupa soal PISA, berdasarkan aspek informasi subjek yang memilki kemampuan berpikir komputasi tinggi memenuhi indikator jelas, tepat, dan relevan. Selain itu subjek tersebut memenuhi indikator tepat dan relevan berdasarkan aspek konsep dan ide, sedangkan pada aspek sudut pandang memenuhi indikator jelas dan luas. Namun, aspek penyimpulan subjek hanya memenuhi indikator logis.
\end{abstract}

Kata kunci: berpikir kritis; berpikir komputasi; penalaran; PISA

\begin{abstract}
The ability of reason and critical thinking of Indonesian students is still relatively low. It can be seen by OECD 2019 which mentions that PISA 2018 result, Indonesia's position is ranked 7th from below. One way to improve critical thinking ability is to familiarize students with implementing computational thinking, that is the process of thinking in solving complex promblems in a variety of simple ways. Therefore this research aims to describe the critical thinking process of being reviewed by students' computational thinking skills. The method used in this research is descriptive with a qualitative approach. The data has collect with tests and interviews. The subject's determination uses a purposive sampling technique by taking three subjects aged 15 years old in Junior High School with the ability to think of high computing, medium, and low. The results showed that in the process of working on a test instrument in the form of PISA, based on the aspect of information the subject with high computational thinking abilities has met clear, precise, and relevant indicators. Also, the subject has met correct and relevant indicators based on the concept and idea aspects. While in the aspect of perspective, the subject has met clear and broad indicators, but in the aspect of the conclusion, the subject only met a logical indicator.
\end{abstract}

Keywords: critical thinking; computational thinking; reasoning; PISA 


\section{PENDAHULUAN}

Tujuan utama PISA (Programme for International Student Assesment) yang diselenggarakan oleh OECD (Organization for Economic Co-operation and Development) adalah mengevaluasi sistem pendidikan secara universal. Selain itu, hasil PISA juga sering digunakan sebagai rujukan untuk mengetahui kualitas pendidikan di dunia, karena PISA mengukur kemampuan literasi membaca, sains, serta matematika siswa yang berusia 15 tahun (Annizar et al., 2020). Hal ini menjadi penting dilihat untuk kepentingan siswa-siswa Indonesia di masa yang akan datang sehingga mampu bersaing dengan negara-negara lain.

Survei PISA 2018, menilai 600.000 siswa yang berusia 15 tahun dari 79 negara. Berdasarkan survei tersebut, diperoleh nilai kemampuan matematika siswa Indonesia sebesar 379, menduduki peringkat ke-7 dari bawah, sedangkan rata-rata negara anggota OECD untuk matematika dan sains adalah 489 (Schleicher, 2019). Perolehan nilai tersebut menunjukkan bahwa kemampuan matematika siswa Indonesia sangat rendah. Itu artinya kemampuan dan penerapan komunikasi matematis, pemecahan masalah serta penalaran siswa Indonesia masih belum optimal (Annizar, 2015). Sehingga dengan melihat hasil PISA tersebut, Indonesia dituntut untuk bercermin dan membenahi diri agar dapat meningkatkan kemampuan matematika siswa di Indonesia (Annizar, 2018).

$\begin{array}{clcr}\text { Fauzi } & \& & \text { Abidin } & \text { (2019) } \\ \text { mengungkapkan } & \text { bahwa } & \text { soal-soal } & \text { PISA }\end{array}$ menuntut kemampuan pemecahan masalah serta kemampuan dalam bernalar. Seorang siswa dapat dikatakan mampu bernalar apabila mampu menerapkan pengetahuannya pada kondisi baru yang belum pernah di kenalinya. Kemampuan inilah yang biasa dikenal dengan kemampuan berpikir kritis. Berpikir kritis merupakan proses berpikir intelektual dengan menilai kualitas berpikirnya yang jernih, reflektif, rasional, dan independen (Ahmatika, 2013). Menurut Fatmawati et al. (2014), berpikir kritis adalah penerapan strategi kognitif atau keterampilan dalam menentukan tujuan yang mengacu langsung pada sasaran, dengan kata lain merupakan bentuk berpikir yang perlu dikembangkan secara tepat dan efektif. Marfuah et al. (2016) menjelaskan bahwa kemampuan berpikir kritis merupakan kemampuan yang sangat fundamental karena berfungsi efektif dalam berbagai aspek kehidupan. Oleh karena itu, kemampuan berpikir kritis sangat penting dan harus ditanamkan sejak dini, baik di rumah, sekolah maupun di lingkungan masyarakat. Salah satu cara menanamkan kemampuan berpikir kritis sejak dini adalah dengan membiasakan siswa menerapkan berpikir komputasi di kehidupan sehari-hari karena menurut Syarifuddin et al. (2019) apabila siswa kerap menggunakan dan menerapkan berpikir komputasi dalam kehidupan sehari-hari, siswa akan lebih mampu berpikir kritis dari biasanya. Di sisi lain, Mufidah (2018) menjelaskan bahwa apabila siswa dapat membiasakan diri dalam mengimplementasikan kemampuan berpikir komputasi guna menyelesaikan masalah di kehidupan sehari-hari, maka siswa tersebut akan lebih berpikir kritis dalam memecahkan suatu permasalahan dengan efektif, dan efisien. Berpikir komputasi adalah rangkaian proses yang dilakukan secara kreatif dalam menerapkan penyelesaian masalah yang meliputi ide, tantangan, dan peluang yang ditemui guna mengembangkan solusi yang dipilih (Fajri et al., 2019). Berbeda halnya menurut Munir (dalam Malik et al., 2018), berpikir komputasi adalah berpikir menggunakan logika, melakukan sesuatu secara bertahap, dan menentukan keputusan jika menghadapi dua kemungkinan yang berbeda. Jadi dapat disimpulkan bahwa berpikir komputasi adalah proses berpikir dalam menyelesaikan masalah yang kompleks dengan berbagai cara sederhana.

Berdasarkan uraian di atas, peneliti merasa penting untuk menganalisis proses berpikir kritis siswa SMP berusia 15 tahun dalam menyelesaikan soal PISA ditinjau dari kemampuan berpikir komputasi yang dimiliki. 
Penelitian ini diharapkan dapat berkontribusi dalam meningkatkan kemampuan matematika siswa Indonesia di masa yang akan datang sehingga mampu bersaing secara global. Oleh sebab itu peneliti mengambil judul "Proses Berpikir Kritis Siswa dalam Menyelesaikan Masalah PISA ditinjau dari Kemampuan Berpikir Komputasi”.

\section{METODE PENELITIAN}

Penelitian ini dilakukan pada salah satu Sekolah Menengah Pertama (SMP) yang terletak di Jember. Instrumen penelitian yang digunakan adalah tes menggunakan soal bebras dan soal PISA yang telah memenuhi kategori valid karena soal-soal tersebut telah digunakan sebagai skala internasional. Tes yang digunakan peneliti yaitu sepuluh soal bebras tingkat SMP berupa soal pilihan ganda dan satu soal PISA berupa soal uraian dengan dua subpertanyaan yang saling berkaitan. Selain itu, instrumen yang digunakan oleh peneliti adalah indikator berpikir kritis Paul dan Elder yang telah dimodifikasi, serta wawancara untuk melengkapi data-data yang diperlukan. Sedangkan teknik penentuan subjek yang digunakan adalah teknik purposive sampling dimana peneliti menentukan pengambilan sampel yang disesuaikan dengan tujuan penelitian. 15 subjek yang merupakan siswa kelas IX berusia 15 tahun, diberi instrumen tes berupa sepuluh soal bebas dengan durasi waktu 30 menit untuk mengukur kemampuan berpikir komputasi siswa yang kemudian dikategorikan berdasarkan pedoman klasifikasi hasil tes.

Tabel 1. Klasifikasi Kemampuan Berpikir Komputasi Berdasarkan Hasil Tes

\begin{tabular}{cc}
\hline Rentang Nilai & Klasifikasi \\
\hline $66,7 \leq$ Nilai & Tinggi \\
$\leq 100$ & \\
$33,4 \leq$ Nilai & Sedang \\
$\leq 66,6$ & Rendah \\
$0 \leq$ Nilai $\leq 33,3$ &
\end{tabular}

Dari 15 siswa, nilai yang didapat berbeda-beda sehingga berdasarkan pedoman klasifikasi kemampuan berpikir komputasi di atas, peneliti mengambil tiga subjek yang mewakili kemampuan berpikir komputasi tinggi, sedang, dan rendah yang kemudian diberi instrumen tes soal PISA untuk mengetahui proses berpikir kritis ke-3 subjek berdasarkan indikator kemampuan berpikir kritis Paul dan Elder yang telah dimodifikasi. Setelah mengerjakan soal PISA, ke-3 subjek diwawancarai sesuai dengan indikator kemampuan berpikir kritis terkait tahapan dalam menyelesaikan soal untuk lebih memperjelas tahapan pengerjaan subjek yang tersirat.

Tabel 2. Indikator Berpikir Kritis

\begin{tabular}{|c|c|c|}
\hline Elemen Bernalar & SIB & Indikator \\
\hline \multirow{3}{*}{ Informasi } & Jelas & $\begin{array}{l}\text { Menuliskan/ } \\
\text { menjelaskan apa } \\
\text { diketahui dari soal }\end{array}$ \\
\hline & Tepat & $\begin{array}{l}\text { Menuliskan/ } \\
\text { menjelaskan apa } \\
\text { yang ditanyakan } \\
\text { pada soal }\end{array}$ \\
\hline & Relevan & $\begin{array}{l}\text { Menuliskan/ } \\
\text { menjelaskan } \\
\text { informasi yang } \\
\text { dibutuhkan tapi tidak } \\
\text { ada di soal }\end{array}$ \\
\hline \multirow{3}{*}{$\begin{array}{l}\text { Konsep dan } \\
\text { Ide }\end{array}$} & Jelas & $\begin{array}{l}\text { Menuliskan/ } \\
\text { menjelaskan rumus } \\
\text { untuk menyelesaikan } \\
\text { soal }\end{array}$ \\
\hline & Tepat & $\begin{array}{l}\text { Menuliskan/ } \\
\text { menjelaskan tahapan } \\
\text { untuk menyelesaikan } \\
\text { soal }\end{array}$ \\
\hline & Relevan & $\begin{array}{l}\text { Menggunakan } \\
\text { informasi dan konsep } \\
\text { sesuai dengan soal }\end{array}$ \\
\hline \multirow{2}{*}{$\begin{array}{l}\text { Sudut } \\
\text { Pandang }\end{array}$} & Jelas & $\begin{array}{l}\text { Menyelesaikan soal } \\
\text { dengan tahapan yang } \\
\text { benar }\end{array}$ \\
\hline & Luas & $\begin{array}{l}\text { Melakukan } \\
\text { pengoreksian } \\
\text { kembali }\end{array}$ \\
\hline Penyimpulan & Logis & $\begin{array}{l}\text { Menuliskan/ } \\
\text { menjelaskan } \\
\text { kesimpulan } \\
\text { berdasarkan konsep } \\
\text { yang benar }\end{array}$ \\
\hline
\end{tabular}


Menuliskan/ menjelaskan

Jelas kesimpulan untuk menjawab soal dengan benar

Berdasarkan pemaparan di atas, analisis proses berpikir kritis subjek menggunakan indikator berpikir kritis Paul dan Elder yang telah dimodifikasi serta menggunakan triangulasi metode untuk menguji keabsahan data. Kemudian dijelaskan langkah demi langkah tentang proses berpikir kritis subjek dalam menyelesaikan instrumen tes soal PISA.

\section{HASIL DAN PEMBAHASAN}

Tes awal diberikan kepada subjek penelitian untuk mengklasifikasikan tingkat kemampuan berpikir komputasi masingmasing subjek. Instrumen tes yang diberikan pada 15 siswa berupa sepuluh butir soal bebras tingkat SMP dalam bentuk pilihan ganda dengan durasi pengerjaan 30 menit. Berdasarkan pedoman klasifikasi hasil tes awal, peneliti mengkategorikan subjek penelitian menjadi subjek yang memiliki kemampuan berpikir komputasi tinggi, sedang, dan rendah.

Tabel 3. Kategori Kemampuan Berpikir Komputasi Berdasarkan Hasil Tes Awal

\begin{tabular}{ccc}
\hline Nilai & Frekuensi & Kategori \\
\hline 70 & 5 siswa & Tinggi \\
50 & 3 siswa & Sedang \\
40 & 2 siswa & \\
30 & 4 siswa & Rendah \\
20 & 1 siswa & \\
\hline
\end{tabular}

Dari data tersebut menunjukkan bahwa dari 15 siswa, didapat lima siswa memiliki kemampuan berpikir komputasi tinggi, lima siswa memiliki kemampuan berpikir komputasi sedang dan lima siswa yang lain memiliki kemampuan berpikir komputasi rendah. Kemudian berdasarkan pedoman klasifikasi hasil tes awal, peneliti memilih tiga subjek yang mewakili masing- masig kategori. S1 sebagai subjek pertama yang memiliki kemampuan komputasi tinggi, S2 sebagai subjek kedua yang memiliki kemampuan komputasi sedang, dan S3 sebagai subjek ketiga yang memiliki kemampuan berpikir komputasi rendah. Selanjutnya ketiga subjek tersebut diberikan tes berupa soal satu PISA dengan dua subpertanyaan yang saling berkaitan lalu dilanjutkan dengan melakukan sesi wawancara sebagai pelengkap data dan memperjelas tahapan-tahapan pengerjaan yang dilakukan oleh ketiga subjek berdasarkan indikator kemampuan berpikir kritis Paul dan Elder yang telah dimodifikasi.

Tabel 4. Kesesuain Proses Berpikir Kritis Subjek Berdasarkan Indikator

\begin{tabular}{lcccc}
\hline \multicolumn{1}{c}{ Elemen } & SIB & S & S & S \\
Bernalar & & 1 & 2 & 3 \\
\hline \multirow{3}{*}{ Informasi } & Jelas & $\checkmark$ & $\checkmark$ & $\checkmark$ \\
& Tepat & $\checkmark$ & & \\
Konsep dan & Relevan & $\checkmark$ & $\checkmark$ & $\checkmark$ \\
Ide & Jelas & $\checkmark$ & $\checkmark$ & \\
Sudut & Tepat & $\checkmark$ & $\checkmark$ & $\checkmark$ \\
Pandang & Relevan & $\checkmark$ & $\checkmark$ & $\checkmark$ \\
Penyimpulan & Jelas & $\checkmark$ & $\checkmark$ & $\checkmark$ \\
& Luas & $\checkmark$ & & \\
& Logis & $\checkmark$ & $\checkmark$ & \\
\hline \multicolumn{1}{c}{ Sedangkan } & Jelas & & & \\
\hline
\end{tabular}

Sedangkan ringkasan dari proses berpikir kritis ketiga subjek adalah sebagai berikut:

Tabel 5. Proses berpikir kritis ketiga subjek

\begin{tabular}{llll}
\hline Elemen & S1 & S2 & S3 \\
Bernalar & & & \\
& Subjek & Subjek & Subjek \\
& menulisk & menjelask & menulisk \\
& an dan & an dan & an apa \\
& menjelask & menuliska & yang \\
& an apa & n sekilas & diketahui \\
& yang & apa yang & pada soal \\
& diketahui & diketahui & dengan \\
Informas & dan & pada soal & simbol, \\
i & ditanyaka & mengguna & namun \\
& n pada & kan & subjek \\
& soal & simbol & tidak \\
& dengan & seperti a & menulisk \\
& kalimat & (U1) dan r & an apa \\
& jelas & (rasio), & yang \\
& (tanpa & namun & diketahui \\
& simbol) & tidak & dan
\end{tabular}


A. C. Lestari, A. M. Annizar/ Jurnal Kiprah 8 (1) (2020) 46-55

\begin{tabular}{|c|c|c|c|c|c|c|c|}
\hline & seperti & menuliska & menulisk & & menyeles & kan & \\
\hline & jumlah & $\mathrm{n} \quad \mathrm{apa}$ & an & & aikan soal & informasi & \\
\hline & bakteri & yang & informasi & & serta & atau & \\
\hline & awal, & ditanyaka & yang & & menggun & konsep & \\
\hline & jumlah & n pada & dibutuhka & & akan & sesuai & \\
\hline & bakteri & soal serta & $\mathrm{n} \quad$ untuk & & informasi & dengan & \\
\hline & setelah 30 & menuliska & menyeles & & atau & soal & \\
\hline & menit dst, & $\mathrm{n}$ & aikan & & konsep & walaupun & \\
\hline & serta & informasi & soal. & & sesuai & kurang & \\
\hline & menulisk & yang & & & dengan & disempur & \\
\hline & & dibutuhka & & & soal. & nakan dan & \\
\hline & informasi & $\mathrm{n} \quad$ untuk & & & & hasil & \\
\hline & yang & menyeles & & & & akhirnya & \\
\hline & dibutuhka & aikan & & & & salah. & \\
\hline & $\mathrm{n}$ untuk & soal. & & & Subjek & Subjek & Subjek \\
\hline & menyeles & & & & menyeles & menyeles & menyeles \\
\hline & aikan soal & & & & aikan soal & aikan soal & aikan soal \\
\hline & walaupun & & & & berdasark & dengan & dengan \\
\hline & tidak & & & & & tahapan- & tahapan \\
\hline & terdapat & & & & langkah- & tahapan & yang \\
\hline & pada soal & & & & langkah & yang & benar \\
\hline & seperti & & & & atau & benar, & namun \\
\hline & mencari & & & & tahapan & namun & tidak \\
\hline & rasio. & & & & yang & tidak & melakuka \\
\hline & Subjek & Subjek & Subjek & Sudut & benar & melakuka & $\mathrm{n}$ \\
\hline & menulisk & menuliska & tidak & Pandang & serta & & pengorek \\
\hline & an dan & $\mathrm{n} \quad$ dan & meuliska & & melakuka & pengoreks & sian \\
\hline & menjelask & menjelask & $\mathrm{n}$ rumus, & & $\mathrm{n}$ & ian ulang & kembali \\
\hline & an rumus & an rumus & namun & & pengorek & sehingga & sehingga \\
\hline & untuk & untuk & menulisk & & sian & hasil & hasil \\
\hline & menyeles & menyeles & & & kembali & akhirnya & akhir \\
\hline & aikan soal & aikan soal & tahapan- & & terhadap & salah. & yang \\
\hline & seperti & walaupun & tahapan & & hasil & & didapat \\
\hline & rumus & rumus & dan & & akhir & & adalah \\
\hline & mencari & yang & menggun & & yang tela & & salah. \\
\hline & rasio dan & dituliskan & akan & & diperoleh. & & \\
\hline & rumus & kurang & informasi & & Subjek & Subjek & Subjek \\
\hline & mencari & benar. & atau & & menulisk & hanya & tidak \\
\hline & baris & Subjek & konsep & & an dan & menuliska & menulisk \\
\hline & geometri. & juga & sesuai & & menjelask & & an \\
\hline & Subjek & menuliska & dengan & & & kesimpula & kesimpul \\
\hline & juga & $\mathrm{n} \quad$ dan & soal & & kesimpul & $\mathrm{n} \quad$ sesuai & an \\
\hline & menulisk & menjelask & walaupun & & an & konsep & apapun \\
\hline & an dan & an & hasil & Penyimp & berdasark & tanpa & untuk \\
\hline & menjelask & tahapan- & akhir & & an konsep & menuliska & memperje \\
\hline & & tahapan & yang & & yang & $\mathrm{n}$ & las yang \\
\hline & tahapan- & untuk & dituliskan & & benar, & kesimpula & ditanyaka \\
\hline & tahapan & menyeles & salah. & & namun & $\mathrm{n} \quad$ untuk & n pada \\
\hline & yang & aikan soal & & & subjek & menjawab & soal. \\
\hline & runtut & dan & & & tidak & soal yang & \\
\hline & dalam & mengguna & & & menulisk & ditanyaka & \\
\hline
\end{tabular}


an

n.

$$
\begin{aligned}
& \text { kesimpul } \\
& \text { an untuk } \\
& \text { menjawa } \\
& \text { b soal } \\
& \text { yang } \\
& \text { ditanyaka } \\
& \text { n. }
\end{aligned}
$$

Saat S1 diberikan tes soal PISA, mulamula $\mathrm{S} 1$ membaca dan memahami tabel dan isi soal, kemudian S1 menuliskan apa yang diketahui dari tabel yang diberikan, yaitu awal $=75$ bakteri; 30 menit $=150 ; 1$ jam $=300 ; 1.5 \mathrm{jam}=600 ; 2 \mathrm{jam}=1200$. Hal ini memenuhi indikator jelas pada aspek informasi. S1 juga menuliskan apa saja yang ditanyakan pada soal, yaitu jumlah bakteri selama 4 jam dan waktu bakteri mencapai 155.600 yang termasuk ke dalam indikator tepat dalam aspek informasi.

Selain itu berdasarkan aspek informasi S1 telah memenuhi indikator relevan karena S1 menuliskan informasi yang dibutuhkan walaupun tidak terdapat dalam soal, ditandai dengan menuliskan bahwa 4 jam $=19200$, dimana setiap kenaikan setengah jam dikalikan dengan 2. Selanjutnya $\mathrm{S} 1$ menuliskan 4 jam $=$ $1200 \times(2 \times 2 \times 2 \times 2)=1200 \times$ $16=19200$, yang memenuhi indikator tepat dan relevan berdasarkan aspek konsep dan ide karena S1 menuliskan tahapan-tahapan dalam menyelesaikan soal dan menggunakan informasi serta konsep sesuai dengan soal. Hal ini sejalan dengan penelitian Sumarmo (2012) bahwa siswa mampu menggunakan pengetahuannya untuk merencanakan penyelesaian soal dari apa yang diketahuinya dengan cara yang lebih sederhana.

Berdasarkan aspek sudut pandang, hal tersebut juga memenuhi indikator jelas dan luas karena berdasarkan wawancara, S1 dapat menjelaskan tahapan-tahapan penyelesaian soal dengan benar dan melakukan pengoreksian kembali untuk memastikan hasil (perkalian) nya benar. Pada subpertanyaan kedua, S1 menuliskan rumus yaitu $U n=$ $a \cdot r^{n-1}, \quad$ dan $\quad \mathrm{r}=U 3 / U 2=300 / 150$ sehingga di dapat $r=2$. Hal tersebut memenuhi indikator relevan dalam aspek informasi karna menuliskan apa yang dibutuhkan namun tidak terdapat pada soal.

Setelah mencari rasio, $\mathrm{S} 1$ menuliskan rumus geometri, yaitu $U n=a \cdot r^{n-1}$ yang termasuk ke dalam indikator jelas berdasarkan aspek konsep dan ide. Kemudian berdasarkan aspek konsep dan ide, S1 telah memenuhi indikator tepat dan relevan yang ditandai dengan menuliskan tahapan-tahapan pengerjaannya dan menggunakan informasi serta konsep sesuai dengan soal, yaitu $\underline{U n}=$ $75 \times 2^{\mathrm{n}-1}=153600$ hingga didapat $n=12$, dan hasil akhir waktunya adalah $\frac{1}{2} \times 12=6$ dan berdasarkan wawancara S1 dapat menjelaskan tahapan-tahapan penyelesaian soal dengan benar dan melakukan pengoreksian kembali hasil akhir, hal ini memenuhi indikator jelas dan luas berdasarkan aspek sudut pandang. Hal ini selaras dengan penelitian Facione (dalam Peter, 2012)bahwa siswa dikatakan mampu berpikir kritis dengan baik jika mereka menggunakan langkahlangkah yang benar dalam menyelesaikan suatu permasalahan dan sesuai dengan penelitian Chukwuyenum (2013) yang menjelaskan bahwa berpikir kritis meliputi usaha seseorang dalam mengumpulkan, menafsirkan, menganalisis dan mengevaluasi informasi untuk sampai pada simpulan yang dapat diandalkan dan valid. Berdasarkan aspek penyimpulan, S1 telah memenuhi indikator logis yang ditandai dengan menuliskan penyimpulan singkat berdasarkan konsep yang benar. 


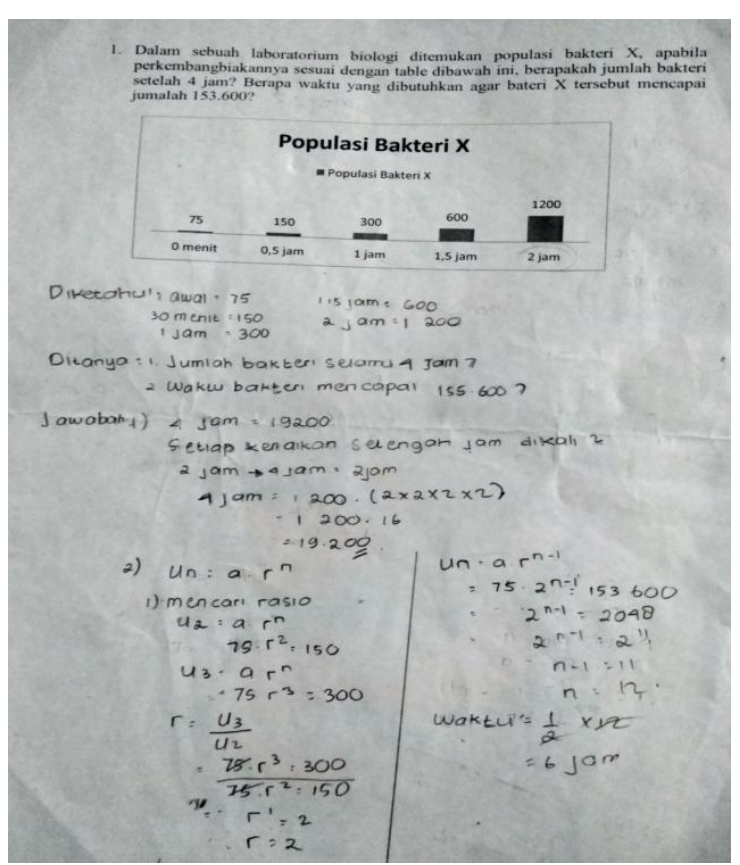

Gambar 1.Hasil Pekerjaan S1

Pada S2, tahapan pertama yang dilakukan adalah membaca soal dan melihat tabel yang tersedia pada soal. Lalu S2 menuliskan apa yang diketahui dari soal dengan singkat, yaitu $a=75$, berdasarkan aspek informasi hal tersebut telah memenuhi indikator jelas, dan menuliskan $r=2$ yang merupakan informasi yang dibutuhkan tapi tidak ada di soal yang sesuai dengan indikator relevan dalam informasi karena berdasarkan hasil wawancara S2 dapat menjawab bahwa $a=2$ berasal dari $\frac{U 3}{U 2}=\frac{300}{150}=2$.

Dalam mengerjakan soal, S2 mengerjakan subpertanyaan kedua terlebih dahulu karena kurang seksama dalam membaca soal.S2 menuliskan rumus $a \times r^{n}$ dan berdasarkan wawancara S2 meyakini bahwa untuk menyelesaikan soal terkait mencari bakteri, virus dan semacamnya menggunakan rumus barisan geometri tapi tanpa menggunakan pangkat minus 1 . Hal ini termasuk ke dalam indikator jelas berdasarkan aspek konsep dan ide. Lalu S2 menuliskan $153600=75 \times 2^{n} \quad$ hingga di dapat $n=$ $11 \mathrm{jam}$, sedangkan jawaban yang benar adalah $n=12$ sehingga waktu yang dibutuhkan bakteri untuk membelah adalah $n \times \frac{1}{2}=12 \times$ $\frac{1}{2}=6$ jam, sesuai dengan indikator tepat dalam aspek konsep dan ide karena S2 menuliskan tahapan penyelesaian soal. S2 telah menyelesaikan subpertanyaan soal kedua dengan tahapan yang benar dan sesuai dengan indikator jelas pada aspek sudut pandang meski tahapan terakhir kurang disempurnakan untuk mendapatkan hasil akhir yang benar, dan S2 tidak melakukan pengoreksian kembali sehingga hasil akhir yang dituliskan adalah salah meskipun hasilnya hampir mendekati jawaban yang benar.

Selanjutnya S2 mengerjakan subpertanyaan pertama dengan membaca ulang soal yang telah diberikan. S2 menuliskan jumlah bakteri setelah 4 jam sesuai dengan indikator logis dalam aspek penyimpulan, lalu S2 menuliskan tahapan penyelesaian soal yang merupakan indikator tepat pada aspek konsep dan ide.

Berdasarkan aspek konsep dan ide, S2 telah memenuhi indikator tepat dan relevan karena menuliskan tahapan penyelesaian soal dan menggunakan informasi atau konsep sesuai dengan soal walapun hasil akhirnya salah karena terburu-buru sehingga S2 ragu terhadap hasil jawabannya. Hal ini sejalan dengan penelitian (Putri \& Fuadiah (2019) yang mengatakan bahwa dalam menyelesaikan soal, siswa bisa merasa ragu dan cemas terhadap jawaban mereka sendiri.

\section{S2 menuliskan}

jumlah bakteri setelah 4 jam $=75 \times$

$2^{8}$ hingga hasil akhinya adalah 19968 , sedangkan hasil yang benar adalah 19200 dengan rumus $U n=a \times r^{n-1}$ sehingga di dapat $75 \times 2^{9-1}=19200$. Dari penulisan tersebut, dapat diketahui bahwa S2 menyelesaikan soal dengan tahapan yang kurang tepat dan tidak melakukan pengoreksian kembali dalam mengalikan angka di tahap akhir, dan konsep sehingga didapat hasil akhir yang salah. Hal ini sesuai dengan penelitian Fatahillah et al. (2017) bahwa hasil penelitian penyebab kesalahan siswa dalam penulisan jawaban akhir adalah tidak menuliskan kesimpulan jawaban atau tidak mengembalikan jawaban $\mathrm{k}$ edalam 
konteks soal, dan menuliskan jawaban dengan perolehan hasil yang salah, dan sejalan dengan penelitian Putri dan Fuadiah (2019)yang berpendapat bahwa faktor penyebab siswa melakukan kesalahan pada tahap penulisan jawaban akhir adalah siswa tidak menulis kesimpulan karena tergesa-gesa dalam menjawab soal, siswa menyimpulkan salah karena kurang teliti.

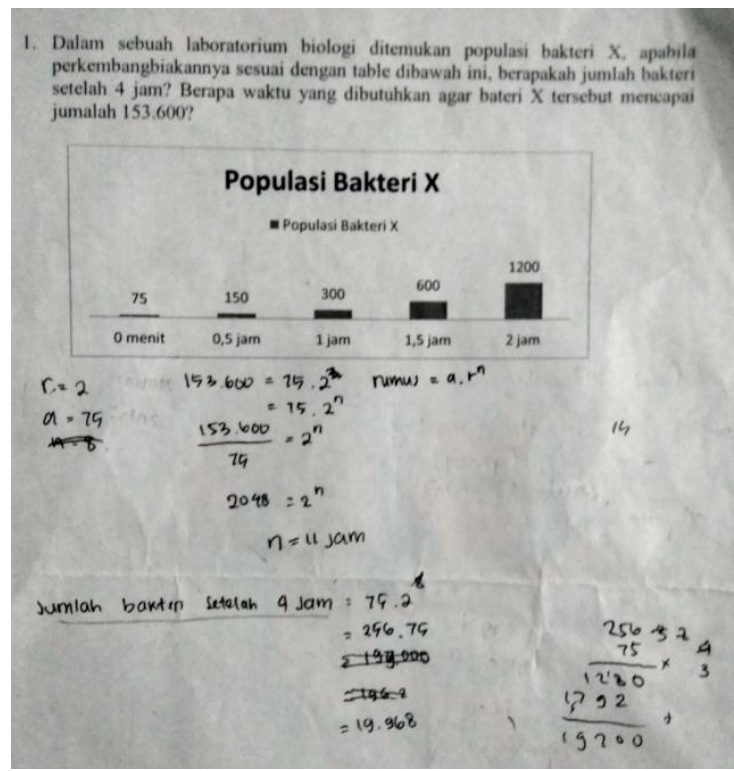

Gambar 2. Hasil Pekerjaan S2

Pada awalnya S3 membaca soal dan memahami tabel pada soal. Kemudian S3 menuliskan $\mathrm{r}=2$ sesuai dengan indikator relevan pada aspek informasi karena S3 menuliskan informasi yang dibutuhkan namun tidak terdapat pada soal, serta berdasarkan wawancara S3 dapat menjelaskan bahwa

$\mathrm{r}=2$ berasal dari $\frac{U 2}{U 1}=\frac{150}{75}=2$.

Berdasarkan aspek informasi, S3 memenuhi indikator jelas karena S3 menuliskan apa yang diketahui dari soal, yaitu $\mathrm{a}=75$ namun tidak menuliskan apa yang ditanyakan pada soal. Hal ini sesuai dengan penelitian yang mengatakan bahwa sebagian besar siswa sudah mampu menyatakan apa yang diketahui dan ditanya dalam soal. Hanya saja ada beberapa siswa yang tidak membuatkan diketahui dan ditanya, ada juga yang hanya membuatkan salah satu dari hal yang diketahui atau ditanya. Hal ini disebabkan karena kebiasaan siswa yang selama ini tidak mau merepotkan dirinya untuk membuat hal tersebut sehingga menurutnya hanya menambah pekerjaan siswa (Khaidir dan Rahmi, 2016).

Untuk menjawab subpertanyaan pertama, S3 menuliskan 4 jam $=75 \times 2^{8}$ hingga didapat hasil akhirnya adalah 19868 . Hal ini sesuai dengan indikator tepat pada aspek konsep dan ide serta berdasarkan aspek sudut pandang S3 telah memenuhi indikator jelas karena S3 telah mampu menuliskan tahapan-tahapan dengan benar dan menggunakan konsep yang sesuai dalam menyelesaikan soal. Pada tahapan akhir, S3 tidak melakukan pengoreksian kembali, sehingga hasil akhir yang dituliskan S3 adalah salah yaitu 19868 sedangkan jawaban yang benar adalah 19200 .

Dalam menyelesaikan subpertanyaan kedua, awalnya S3 menuliskan $153600=$ $75 \times 2^{n}$ hingga didapat hasil akhirnya adalah $10 \mathrm{jam}$. Hal ini sesuai dengan indikator relevan pada aspek konsep dan ide karena S3 menggunakan informasi dan konsep sesuai dengan soal. Dalam menyelesaikan soal, S3 menuliskan tahapan-tahapan yang kurang lengkap dan tidak melakukan pengoreksian kembali sehingga hasil akhir yang ditulis adalah jawaban yang salah, yaitu 19868 yang merupakan hasil perkalian $256 \times 75$, padahal jawaban yang benar dari perkalian $256 \times 75$ adalah 19200. Hal ini sesuai dengan pendapat Laksono (2013) bahwa siswa tidak cermat dalam proses pengerjaannya karena siswa cenderung tergesa-gesa dalam menjawab soal tanpa menelaah terlebih dahulu. Sehingga menurut Supriadi et al. (2015) siswa yang memiliki kemampuan berpikir kurang (rendah), perlu mendapatkan bimbingan dari pendidik untuk menyelesaikan suatu permasalahan. 


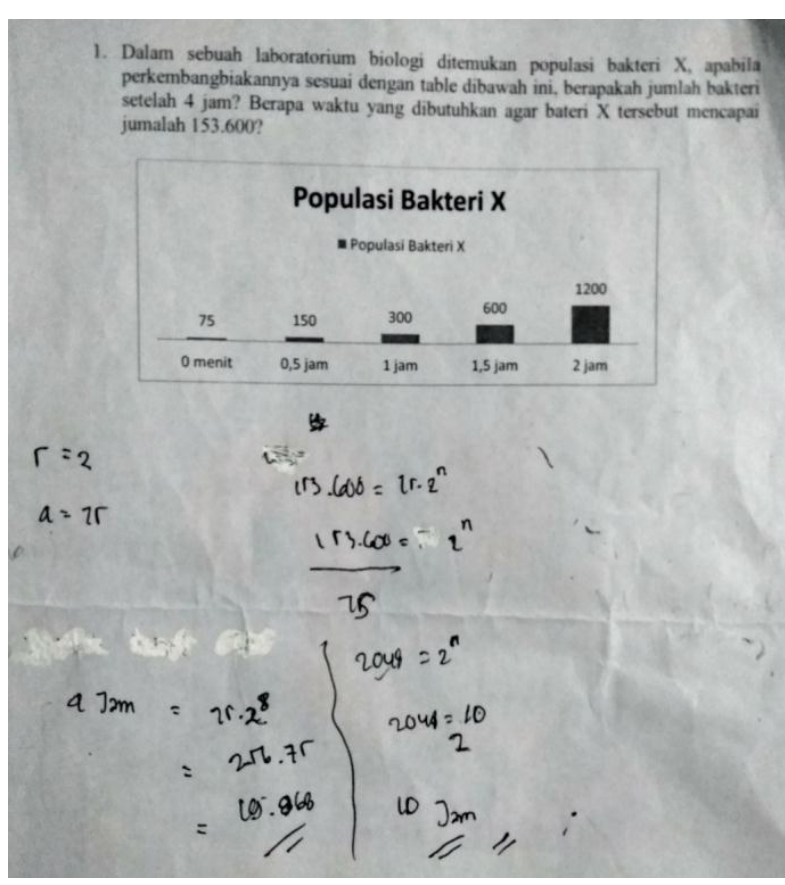

Gambar 3. Hasil Pekerjaan S3

\section{KESIMPULAN}

Berdasarkan hasil dan pembahasan penelitian di atas dapat disimpulkan bahwa subjek yang memiliki kemampuan berpikir komputasi tinggi memenuhi indikator jelas, tepat, relevan pada aspek informasi karena subjek tersebut menuliskan dan menjelaskan apa yang diketahui dan ditanyakan pada soal dengan kalimat jelas dan menuliskan informasi yang dibutuhkan untuk menyelesaikan soal walaupun tidak terdapat pada soal. Pada aspek konsep dan ide, subjek memenuhi indikator jelas, tepat, dan relevan ditandai dengan menuliskan serta menjelaskan rumus untuk menyelesaikan soal dan tahapan-tahapan yang runtut dalam menyelesaikan soal, juga menggunakan informasi atau konsep sesuai dengan soal. Pada aspek sudut pandang, subjek memenuhi indikator jelas dan luas karena subjek mampu menyelesaikan soal berdasarkan langkah-langkah atau tahapan yang benar serta melakukan pengoreksian kembali terhadap hasil akhir yang tela diperoleh. Pada aspek penyimpulan, subjek memenuhi indikator logis karena subjek mampu menuliskan dan menjelaskan kesimpulan berdasarkan konsep yang benar.

$$
\text { Pada subjek yang memiliki }
$$

kemampuan berpikir komputasi sedang memenuhi indikator jelas dan relevan pada aspek informasi karena subjek menjelaskan dan menuliskan sekilas apa yang diketahui pada soal menggunakan simbol serta menuliskan informasi yang dibutuhkan untuk menyelesaikan soal. Subjek juga memenuhi indikator jelas dan tepat pada aspek konsep dan ide karena subjek menuliskan dan menjelaskan rumus untuk menyelesaikan soal walaupun rumus yang dituliskan kurang benar, menuliskan dan menjelaskan tahapan-tahapan untuk menyelesaikan soal dan menggunakan informasi atau konsep sesuai dengan soal walaupun tahap akhirnya kurang disempurnakan. Pada aspek sudut pandang, subjek memenuhi indikator jelas karena subjek mampu menyelesaikan soal dengan tahapantahapan yang benar walaupun hasil akhirnya salah, sedangkan pada aspek penyimpulan, subjek memenuhi indikator logis karena subjek hanya menuliskan kesimpulan sesuai konsep.

Sebaliknya pada subjek yang memiliki kemampuan berpikir komputasi rendah, memenuhi indikator jelas dan relevan pada aspek informasikarena subjek menuliskan apa yang diketahui pada soal dengan singkat dan menuliskan informasi yang dibutuhkan untuk menyelesaikan soal. Subjek juga memenuhi indikator tepat dan relevan pada aspek konsep dan ide karena subjek menuliskan tahapantahapan dan menggunakan informasi atau konsep sesuai dengan soal walaupun hasil akhir yang dituliskan salah dan subjek hanya memenuhi indikator jelas pada aspek sudut pandang karena subjek hanya menyelesaikan soal dengan tahapan yang benar namun tidak melakukan pengoreksian kembali sehingga hasil akhir yang didapat adalah salah.

\section{UCAPAN TERIMA KASIH}

Penulis ucapkan terima kasih kepada Ketua Program Studi Tadris Matematika, Dekan Fakultas Tarbiyah dan Ilmu Keguruan, serta Rektor IAIN Jember atas dukungannya. Artikel ini menggunakan dana yang bersumber dari penulis secara mandiri.

\section{REFERENSI}

Ahmatika, D. (2013). Peningkatan Kemampuan Berpikir Kritis Siswa Dengan Pendekatan Inquiry/Discovery. Jurnal Euclid, 3(1), 394-403.

Annizar, A. M. (2015). Analisis Kemampuan

Pemecahan Masalah Soal PISA Menggunakan Model IDEAL Pada Siswa 
Usia 15 Tahun di SMA Nuris Jember.

Annizar, A. M., Maulyda, M. A., Khairunnisa, G. F., \& Hijriani, L. (2020). Kemampuan Pemecahan Masalah Matematis Siswa dalam Menyelesaikan Soal PISA pada Topik Geometri. Jurnal Elemen, 6(1), 39-55.

https://doi.org/10.29408/jel.v6i1.1688

Annizar, A. M., Sisworo, \& Sudirman. (2018). Pemecahan Masalah menggunakan Model IDEAL pada Siswa Kelas $\mathrm{X}$ Berkategori Fast-Accurate. Jurnal Pendidikan: Teori, Penelitian, Dan Pengembangan, 3(5), 634-640.

Chukwuyenum, A. N. (2013). Impact of Critical thinking on Performance in Mathematics among Senior Secondary School Students in Lagos State. IOSR Journal of Reasearch \& Method in Education, 3(5), 18-25.

Fajri, M., Yurniwati, \& Utomo, E. (2019). Computational Thinking, Mathematical Thinking Berorientasi Gaya Kognitif pada Pembelajaran Matematika di Sekolah Dasar. Dinamika Sekolah Dasar, 1-18.

Fatahillah, A., Wati, Y. F., \& Susanto. (2017). Analisis Kesalahan Siswa dalam Menyelesaikan Soal Cerita Matematika Berdasarkan Tahapan Newman Beserta Bentuk Scaffolding yang Diberikan. Kadikma, 8(1), 40-51.

Fatmawati, H., Mardiyana, \& Triyanto. (2014). Analisis Berpikir Kritis Siswa dalam Pemecahan Masalah matematika Berdasarkan Polya pada Pokok Bahasan Persamaan Kuadrat. Jurnal Elektronik Pembelajaran Matematiika, 2(9), 911922.

Fauzi, A. M., \& Abidin, Z. (2019). Analisis Keterampilan Berpikir Kritis Tipe Kepribadian Thinking-Feeling dalam menyelesaikan Soal PISA. Suska Journal of Mathematics Education, 5(1), 1-8.

Khaidir, C., \& Rahmi, E. (2016). Analisis Kesalahan Siswa dalam Menyelesaikan Soal Cerita Matematika Kelas X.2 SMAN 1 Salimpaung Berdasarkan Metode Kesalahan Newman. Proceeding International Seminar on Education 2016, 103-110.

Laksono, R. D. (2013). Peranan Kretivitas dalam Belajar dengan Acang
Menggunakan Media Moodle. Jurnal Ilmiah STKIP PGRI Ngawi, 11(1), 5964.

Malik, S., Prabawa, H. W., \& Rusnayati, H. (2018). Peningkatan Kemampuan Berpikir Komputasi Siswa Melalui Multimedia Interaktif Berbasis Model Quantum Teaching and Learning. November. https://doi.org/10.13140/RG.2.2.34438.8 3526

Marfuah, I., Mardiyana, \& Subanti, S. (2016). Proses Berpikir Kritis Peserta Didik dalam dua Variabel Ditinjau dari Gaya Belajar Kelas IX B SMP Negeri 2 Surakarta. Jurnal Elektronik Pembelajaran Matematiika, 4(7), 622632.

Peter, E. E. (2012). Critical thinking: Essence for teaching mathematics and mathematics problem solving skills. African Journal of Mathematics and Computer Science Research, 5(3), 39-43. https://doi.org/10.5897/AJMCSR11.161

Pratiwi, I. (2019). Efek Program PISA Terhadap Kurikulum di Indonesia. Jurnal Pendidikan Dan Kebudayaan, 4(1), 5171.

Putri, S. M., \& Fuadiah, N. F. (2019). Identifikasi Kesalahan Siswa Berdasarkan Newman dalam Menyelesaikan Soal Pada Materi Persamaan Kuadrat Tingkat Sekolah Menengah Pertama. Jurnal Silogisme Kajian Ilmu Matematika Dan Pembelajarannya, 4(1), 21-29.

Schleicher, A. (2019). PISA 2018: Insights and Interpretations. $O E C D, 3-62$.

Supriadi, D., Mardiyana, \& Subanti, S. (2015). Analisis Proses Berpikir Siswa dalam Memecahkan Masalah Matematika Berdasarkan Langkah Polya Ditinjau Dari Kecerdasan Emosional Siswa Kelas VIII SMP Al Azhar Syifa Budi Tahun Pelajaran 2013/2014. Jurnal Elektronik Pembelajaran Matematiika, 3(2), 204214.

Syarifuddin, M., Risa, D. F., Hanifah, A. I., \& Nurussa'adah. (2019). Jurnal Mitra Pendidikan ( JMP Online ). Jurnal Mitra Pendidikan, 3(6), 807-822. 